\title{
Feto-Maternal Outcome and Complications of Emergency Caesarean Section among the Patients Admitted at a Tertiary Care Hospital in Dhaka City
}

\author{
Rifat Sultana1*, Aftabun Nahar², Fatema Mahbooba Akter², Rabeya Sultana3 ${ }^{3}$, Afroza Ghani4, \\ Md. Abdullah Yusuf ${ }^{5}$
}

${ }^{1}$ Department of Gynaecology \& Obstetrics, Shaheed Taj Uddin Ahmad Medical College, Gajipur, Bangladesh

${ }^{2}$ Department of Gynaecology \& Obstetrics, Mugda Medical College, Dhaka, Bangladesh

${ }^{3}$ Department of Gynaecology \& Obstetrics, City Medical College, Gazipur, Bangladesh

${ }^{4}$ Department of Gynaecology \& Obstetrics, Shaheed Suhrawardy Medical College, Dhaka, Bangladesh

${ }^{5}$ Department of Microbiology, National Institute of Neurosciences \& Hospital, Dhaka, Bangladesh

Email: ^dr.rifat.sultana@gmail.com,draftabun@gmail.com, fatema95@gmail.com,s.rabeya@ymail.com,

ghaniafrozabula@gmail.com, ayusuf75@yahoo.com

How to cite this paper: Sultana, R., Nahar, A., Akter, F.M., Sultana, R., Ghani, A. and Yusuf, Md.A. (2016) Feto-Maternal Outcome and Complications of Emergency Caesarean Section among the Patients Admitted at a Tertiary Care Hospital in Dhaka City. Open Journal of Obstetrics and Gynecology, 6, 874878.

http://dx.doi.org/10.4236/ojog.2016.613105

Received: October 5, 2016

Accepted: December 23, 2016

Published: December 26, 2016

Copyright $\odot 2016$ by authors and Scientific Research Publishing Inc. This work is licensed under the Creative Commons Attribution-NonCommercial International

License (CC BY-NC 4.0).

http://creativecommons.org/licenses/by-nc/4.0/ (c) (i) \& Open Access

\section{Abstract}

Background: Caesarean Section done in emergency basis can result some adverse outcome to both the fetus \& mother \& complications may arise. Objective: The purpose of the present study was to see the fetal \& maternal outcome or any complications among the pregnant woman who had undergone emergency caesarean section. Methodology: This descriptive type of cross sectional study was conducted in the Department of Gynaecology \& Obstetrics at Dhaka Medical College Hospital during the period from July 2006 to December 2006. The patients underwent emergency caesarean section for any indication during the mentioned period of study was selected as study population. Among them, 100 cases were recruited in this study. Result: Among the cases, maternal morbidity was as high as $64 \%$ which were due to haemorrhage, post-operative infection, rise of blood pressure and other complications. Regarding fetal outcome, $92 \%$ babies were born with normal birth weight, 33\% babies were developed complications which were mostly due to birth asphyxia and prematurity. Conclusion: In conclusion, emergency caesarean section has maternal morbidity as well as fetal and neonatal adverse outcome.

\section{Keywords}

Foetal Outcome, Neonatal Outcome, Maternal Outcome, Emergency

Caesarean Section 


\section{Introduction}

Child birth is a universally celebrated event, yet many thousands of women each day, child birth is experienced not as the joyful event it should be [1]. Pregnancy and parturition should be regarded as a natural and physiological event; however it may be pathological any time before, during and after delivery.

Globally every year about 500,000 maternal deaths and 5 - 6 million perinatal deaths occur and $99 \%$ of them are in the developing world [2] [3]. The safe motherhood initiative is a global effort to reduce maternal mortality and morbidity and to achieve a healthy baby by proper management of obstetrical problems. Caesarean section is the most frequently performed major operation in obstetrics and plays an important role in this respect [4]. Modern obstetric care includes liberalized use of caesarean section and it steadily increases in the past 20 years [1]. In emergency situation, caesarean section is done due to unforeseen complication arising either during pregnancy or during labour; this acts as a life saving measure for both the mother and fetus [3]. Every operative procedure has its own hazards; thus, caesarean section is also not free from them [2]. In Bangladesh, the obstetrics care has improved; however, this is not optimal to reduce the maternal mortality and morbidity. During delivery the fetal outcome is also important. Though the rate of fetal mortality and morbidity has been improved the overall scenario of emergency caesarian section is not evaluated. In this regards, it is indispensable to know the situation of feto-maternal morbidity and mortality in Bangladesh [5]. Therefore, the present study was undertaken to observe the maternal and fetal outcome among the pregnant women who had undergone emergency caesarean section.

\section{Methodology}

This descriptive type of cross sectional study was conducted in the Department of Gynaecology and Obstetrics at Dhaka Medical College Hospital, Dhaka the busiest tertiary care hospital in Bangladesh, during the period from July 2006 to December 2006 for a period of six (06) months. The patients underwent emergency caesarean section for any indication during the mentioned period of study was selected as study population. The cases were selected by random sampling from the patients with an indication of emergency caesarean section but with stable general condition at that moment. Every 10th patient was selected for the study. Data were collected after taking written consent from the properly selected patients. At first, thorough history as per prepared questionnaire, then clinical examination was done and information was collected. Intraoperative complications were noted. With follow up monitoring, post-operative complications were observed. Foetal outcome were noted. All relevant clinical information of the cases was recorded systematically in the predesigned clinical data sheet. Data were checked, verified and complied by computer; analysis was done by using SPSS and the results were displayed in tables.

\section{Results}

A total number of 100 emergency caesarian section cases were recruited for this study 
after fulfilling the inclusion and exclusion criteria. Among the study population postoperative complication was reported in $64(64.0 \%)$ cases and the rest $36(36.0 \%)$ cases were without any complications (Table 1 ).

Among the 64 maternal complications the most common reported condition was per-operative haemorrhage which was $20(31.3 \%)$ followed by wound infection and UTI which were $18(28.1 \%)$ cases and 9 (14.1\%) cases respectively (Table 2).

Table 3 shows that most of the babies (92\%) were born with normal ( $2.5 \mathrm{~kg}$ to 3.5 $\mathrm{kg}$ ) birth weight (Table 3).

Table 4 shows that foetal complication occurred in $33.0 \%$ cases (Table 4 ).

Among 33 fetal outcomes with complication the most common complication was Birth asphyxia which was 8 (24.2\%) cases followed by prematurity, neonatal infection and neonatal jaundice which were $7(21.2 \%)$ cases, $6(18.2 \%)$ cases and 5 (15.1\%) cases respectively (Table 5).

\section{Discussion}

This study was designed to evaluate the maternal and foetal outcome in emergency

Table 1. Post-operative maternal complications.

\begin{tabular}{ccc}
\hline Conditions & Frequency & Percentage \\
\hline With complications & 64 & 64.0 \\
Without complications & 36 & 36.0 \\
Total & 100 & 100.0 \\
\hline
\end{tabular}

Table 2. Maternal outcome found among the study population.

\begin{tabular}{ccc}
\hline Conditions & Frequency & Percentage \\
\hline Haemorrhage* & 20 & 31.3 \\
Wound infection & 18 & 28.1 \\
Puerperal Pyrexia & 4 & 6.2 \\
UTI & 9 & 14.1 \\
Anaemia & 3 & 4.7 \\
Headache & 5 & 7.8 \\
Cardiac arrest & 1 & 1.6 \\
Post-operative rise of BP & 4 & 6.2 \\
Total & 64 & 100.0 \\
\hline
\end{tabular}

*Both Per-operative and PPH (Primary \& Secondary).

Table 3. Outcome of baby according to birth weight.

\begin{tabular}{ccc}
\hline Weight & Frequency & Percentage \\
\hline$<2.5 \mathrm{~kg}$ & 8 & 8.0 \\
$2.5 \mathrm{~kg}-3.5 \mathrm{~kg}$ & 92 & 92.0 \\
Total & 100 & 100.0 \\
\hline
\end{tabular}


Table 4. Post-operative fetal complications.

\begin{tabular}{ccc}
\hline Conditions & Frequency & Percentage \\
\hline With complications & 33 & 33.0 \\
Without complications & 67 & 67.0 \\
Total & 100 & 100.0 \\
\hline
\end{tabular}

Table 5. Foetal outcome found among the study population.

\begin{tabular}{ccc}
\hline Conditions & Frequency & Percentage \\
\hline Neonatal Jaundice & 5 & 15.1 \\
Prematurity & 7 & 21.2 \\
Neonatal Infection & 6 & 18.2 \\
Birth asphyxia & 8 & 24.2 \\
Perinatal death & 4 & 12.2 \\
Congenital anomaly & 1 & 3.0 \\
Neonatal death & 2 & 6.1 \\
Total & 33 & 100.0 \\
\hline
\end{tabular}

caesarean section. Several similar types of studies were undertaken in Bangladesh by different researchers to reduce the incidence \& complication of emergency caesarean section and to achieve a healthy mother and a healthy baby by proper management of obstetrical problems.

This study reveals that majority (64\%) cases developed complication. Among the complications, haemorrage was $20.0 \%$, which occurred from surgical incision and atony of the uterus \& were managed appropriately. Other complications were wound infection $18.0 \%$, anaemia $3.0 \%$, puerperal pyrexia $4.0 \%$, UTI $9.0 \%$, headache $5.0 \%$, postoperative rise of BP $4.0 \%$, one case developed cardiac arrest due to anaesthetic complication. Complications like wound infection, febrile morbidity and endometritis were found more in case of preoperative rupture of membranes prolong duration of labour \& repeated per vaginal examination. In a study conducted by Chowdhury et al. [6] at SSMC \& Mitford Hospital, incidence of wound sepsis was $18.28 \%$, anaemia 7.1\%, which were higher than this study. Another study was carried out by Begum [7] in 300 cases among the admitted patients of Dhaka Medical College Hospital \& found that wound infection $35.5 \%$ which is also higher than this study. This study can also be compared with other studies which were undertaken in abroad. A study by Watson et al. [8] has got wound infection in only $1.54 \%$ cases UTI in $4.64 \%$ after emergency caesarean section which is much less than my study.

In this study, foetal outcome of emergency caesarean section was not good. Here 33\% of the babies developed complications and $67 \%$ were healthy. Among the complications, $5 \%$ developed jaundice, $7 \%$ were premature baby delivered due to maternal morbidity, $6 \%$ developed neonatal infection, $8 \%$ developed birth asphyxia, $2 \%$ were neonat- 
al death and perinatal death were $4 \%$. These findings are far better than that of Tedesse et al. [9] at Ethopia in which stillbirth was $4.8 \%$ and neonatal death were $4.7 \%$. However, findings of this study were higher than Dey and Hatai [10] at Calcutta. They found that neonatal complications were $21.8 \%$ in emergency caesarean section and $15.5 \%$ in elective caesarean section.

\section{Conclusion}

Caesarean section, a major surgical procedure for obstetrical management, however, it still has got some morbidity and mortality for the mother and baby. So, it is necessary to take consideration of all the points related to emergency caesarean section along with the factors responsible for emergency caesarean section and outcome of this should be studied much more. Thereby the incidence and complications can be reduced.

\section{References}

[1] Royson, E. and Armstrong, F. (1989) Preventing Maternal Deaths. World Health Organization, Geneva, 9-10.

[2] Ratnum, S.S., Rao, K.B. and Arulkumarans, S. (1992) Obstetrics \& Gynaecology for Postgraduates. 2nd Edition, Orient Longman, Hyderabad, 10-14, 145-152.

[3] Azim, A.K.M.A., Salauddin, G. and Bari, M.A. (2000) A Study of MCH Service among the Slum Dwellers of Dhaka City. Bangladesh Journal of Obstetrics \& Gynaecology, 20, 10-14.

[4] Nahar, K. and Nahar, N. (2005) Emergency Obstetric Hysterectomy-65 Cases. Bangladesh Journal of Obstetrics \& Gynaecology, 20, 47-50.

[5] Maternal Health and Safe Motherhood Programme. Annex 2, Division of Family Planning. WHO/FHE/MSM/94; 11: 95.

[6] Chowdhury, S.B., Newaz, R., Begum, A. and Dewan, F. (1994) Indications and Complications of Caesarean Section-A Study of 1083 Cases. Bangladesh Journal of Obstetrics \& Gynaecology, 9, 1-7.

[7] Begum, A. (1990) Post Caesarean Wound Infection-An Analysis of Prevalence and Predisposing Factors. Bangladesh Medical Journal, 19, 3-7.

[8] Watson, W.J., George, R.J., Welter, S. and Day, D. (1997) High-Risk Obstetric Patients. Maternal Morbidity after Cesareans. The Journal of Reproductive Medicine, 42, 267-270.

[9] Tedesse, E., Adane, M. and Abiyou, M. (1999) Caesarean Section Deliveries at Tikur Anbessa Teaching Hospital, Ethiopia. East African Medical Journal, 73, 619-622.

[10] Dey, N. and Hatai, S.K. (1992) A Study of Caesarean Section Cases with Special References to Maternal and Neonatal Outcome. Journal of Indian Medical Association, 90, 149-151. 
Submit or recommend next manuscript to SCIRP and we will provide best service for you:

Accepting pre-submission inquiries through Email, Facebook, LinkedIn, Twitter, etc. A wide selection of journals (inclusive of 9 subjects, more than 200 journals)

Providing 24-hour high-quality service

User-friendly online submission system

Fair and swift peer-review system

Efficient typesetting and proofreading procedure

Display of the result of downloads and visits, as well as the number of cited articles

Maximum dissemination of your research work

Submit your manuscript at: http://papersubmission.scirp.org/

Or contact ojog@scirp.org 